\title{
QUE TÊMIS POSSA PERFORMAR: POR UMA TEORIA EXPANSIVA DO "HUMANO" NO DIREITO'
}

\author{
So that Themis can perform: for an expansive \\ theory of the "human" in Law \\ Que Themis puede realizarse: para una \\ teoría expansiva del "humano" en el derecho
}

Camilla de Magalhães Gomes²

Centro Universitário de Brasília, Brasília, DF, Brasil.

\section{Resumo}

Guiado pelas teorias da decolonialidade e da performatividade, este artigo pretende discutir as possibilidades de uma teoria do humano no Direito que seja expansiva, rompendo com as leituras cis-heteronormativas e brancas das teorias dominantes sobre Direito e Justiça. Para isso, realiza duas tarefas: primeiro, toma as teorias sobre sexo, gênero e raça como linguagens atribuídas a corpos para usar o corpo como categoria jurídica de análise e, com esse corpo, aprendendo com as travestilidades, compre-

\footnotetext{
Este texto é parte das conclusões de minha tese de doutoramento defendida no Programa de Pós-Graduação em Direito, Estado e Constituição, da Universidade de Brasília, disponível no repositório institucional (MAGALHÃES GOMES, 2017)

2 Doutora em Direito, Estado e Constituição pela Universidade de Brasília. Professora de Direito Penal e Processo Penal do Centro Universitário de Brasília (UniCEUB) e Professora do Projeto de Extensão de proteção a mulheres vítimas de violência Doméstica - (PROVID) da UniCEUB. https://orcid.org/0000-0001-6993-7289.E-mail: camillamaggo@gmail.com
} 
ender o humano como sempre sendo "em processo de", exigindo-nos compromisso com "dignidades" produzidas a partir da multiplicidade da "pessoa". Depois, usa duas categorias jurídico-constitucionais para rediscutir a entrada do "humano" no Direito nos marcos do gênero e da raça - e das múltiplas corporalidades: dignidade da pessoa humana e povo. Sem pretender resolver a oposição universalismo/individualismo contida nessas categorias, o trabalho sustenta a fronteira como lugar de expansão: um povo que performa pluriversalidades e a pessoa humana em suas multiplicidades. Essa teoria expansiva exige reconhecer que o humano é humano "em processo de" e coloca o limite dos sentidos produzidos pela tensão entre as duas categorias jurídicas no corpo, lido sob as linguagens de sexo, gênero e raça. Isso exigirá o compromisso e a responsabilização pela diminuição da distribuição diferencial de humanidade produzida na matriz branca e cis-heterconforme e o reconhecimento de que o sujeito que dá a si mesmo a "lei" deve poder se fazer mutuamente povo e pessoa humana.

Palavras-chave: Povo. Dignidade da pessoa humana. Raça. Gênero.

\section{Abstract}

Guided by the theories of decoloniality and performativity, this article aims to discuss the possibilities of an expansive theory of the human in law, breaking with the cis-heteronormative and white readings of the dominant theories on Law and Justice. In order to do this, it performs two tasks: first, it takes the theories on sex, gender and race as languages attributed to bodies to use the body as a legal category of analysis and, with this body, learning with the "travestilidades", understand the human as always being in the process of, demanding from us a commitment with dignities produced from the multiplicity of the person. It then uses two legal-constitutional categories to rediscuss the entry of the "human" in Law into the framework of gender and race and the manifold corporealities: the human dignity and the people. Without aiming to solve the universalism/individualism opposition contained in these categories, it argues the frontier as a place of expansion: a people that perform pluriversalitiess and the human person in their multiplicities. This expansive theory requires recognizing that the human being is in the process of and places the limit of the senses produced by the tension between the two categories in the body, which will require the commitment and the responsibility for diminishing the differential distribution of humanity produced in the white cis-heteroconforming matrix and the recognition that the subject who gives himself the "law" must be able to make himself a people and a human person.

Keywords: People. Human dignity. Race. Gender. 


\section{Resumen}

Guiados por las teorías de la decolonialidad y de la performatividad, este artículo discutirá las posibilidades de una teoría del humano en el Derecho que pueda ser expansiva, rompiendo con lecturas cis-heteronormativas y blancas de las teorías dominantes sobre el Derecho y Justicia. Para ello, realiza dos tareas: primero, toma las teorías sobre sexo, género y raza como lenguajes asignadas a cuerpos para utilizar el cuerpo como categoría jurídica y de análisis y, con ese cuerpo, aprendiendo con las travestilidades, comprendiendo al ser humano como siempre siendo en el proceso de, que nos requiere el compromiso con las dignidades producidas a partir de la multiplicidad de la persona. Luego, utiliza dos categorías jurídico-constitucionales para revisar la entrada del "humano" en el Derecho en el marco del género y de la raza - y de las múltiples corporalidades: dignidad de la persona humana y del pueblo. Sin pretender resolver la oposición universalismo/individualismo contenida en estas categorías, la investigación sostiene la frontera como lugar de expansión: un pueblo que realiza pluriversalidades y la persona humana en sus multiplicidades. Esta teoría expansiva requiere reconocer que el ser humano es humano en proceso de y establece el límite de los sentidos producidos por la tensión entre las dos categorías jurídicas en el cuerpo, sob una perspectiva de lectura acerca de las lenguajes, de sexo, de género y de raza. Esto requerirá el compromiso y responsabilidad por reducción de la distribución diferencial de la humanidad producida en la matriz blanca y cis-heterconforme y el reconocimiento que el sujeto que se da la "ley" debe ser capaz de se hacer mutuamente pueblo y persona humana.

Palabras claves: Pueblo. Dignidad de la persona humana. Raza. Género.

"Si no nos cuidamos, la mejor alegoría del derecho de las minorías en el mundo globalizado estará dada por las transformaciones de la muñeca Barbie que, frente a las críticas al modelo anglosa jón de belleza que impone, apareció con ropas étnicas y piel más oscura. Sin embargo, la estructura ósea que se adivina por debajo de la piel es la misma". (Rita L. Segato)

"Perguntar-se sobre o que "nos" faz diferentes dos outros - outras espécies ou outras culturas, pouco importa quem são "eles" quando o que importa somos "nós" - já é uma resposta" (Eduardo Viveiros de Castro)

"Travesti não é bagunça, afinal". (Viviane Vergueiro) 


\section{Introdução}

O Direito fala do humano. Trata de aspectos variados do humano, suas relações, sua constituição, sua dignidade, sua associação, sua personificação. Mas o que é esse humano? Ou melhor, como o "humano" entra no Direito? Quando falo de o humano "entrar" no Direito, parto da seguinte consideração: o Direito tem força performativa ${ }^{3}$, cria a sua realidade, é, em sua maioria, uma espécie de linguagem que faz algo, seja por uma produção de efeitos, seja por uma força. E cria, portanto, os próprios sujeitos de que fala, cria um "humano". É nessa linha, então, que este artigo tem por objetivo pensar uma outra forma de fazer o humano entrar no Direito, uma forma expansiva, uma forma que rompa com as leituras cis-heteronormativas e brancas das teorias dominantes sobre o Direito e a Justiça e faz isso em dois passos: primeiro, toma as teorias sobre sexo, gênero e raça - com a associação das teorias da performatividade ${ }^{4}$ e da decolonialidade 5 - como

\footnotetext{
3 A esse respeito: DERRIDA, Jacques. Declarations of Independence. In: DERRIDA, Jacques. Negotiations. Trad. Elizabeth G. Rottenberg. Stanford: Stanford University Press, 2002, p. 46-54. MACIEL, Anna Maria Becker.Para o reconhecimento da especificidade do termo jurídico. Tese (Doutorado). Programa de Pós-Graduação em Letras, Universidade Federal do Rio Grande do Sul, Porto Alegre, 2001. A teoria sobre os atos de fala performativos é construída por John Austin (1975). Adoto aqui, contudo, a postura a respeito da performatividade construída pela linha derridiana, em especial pelas leituras do autor argelino feitas por Judith Butler (1997a), Shoshana Felman (2003) e Timothy Gould (1995), sobre a qual comentei em outra oportunidade (MAGALHÃES GOMES, 2017a e 2017b).
}

4 Sobre teorias da performatividade, estou me referindo a dois aspectos. Primeiro à teoria de John Austin (1975) sobre a linguagem e sua divisão em atos de fala performativos e constatativos e as revisitações a essa teoria, especialmente as promovidas por Jacques Derrida, Judith Butler, Shoshana Felman e Timothy Gould. Além disso, refiro-me também à teoria do gênero como performatividade, conforme obra de Judith Butler.

5 Colonialidade e colonialismo não são sinônimos, portanto. Enquanto o último serve a significar os processos e aparatos de "dominação política e militar que são implantados para garantir a exploração do trabalho e a riqueza das colônias para o benefício do colonizador" (RESTREPO; ROJAS, 2010, p. 15), como relação política e econômica "em que a soberania de um povo reside no poder de outro povo ou nação, que é a nação em um império" (MALDONADO-TORRES, 2007, p. 131); o primeiro é bem mais amplo e complexo e está no colonialismo ao mesmo tempo que o sucede e a ele sobrevive, e quer significar um padrão de poder como resultado daquele. Não há ruptura ou descontinuidade, como se o fim dos períodos coloniais - falo períodos para destacar a diferença dos processos de descolonização latino-americanos e aqueles dos países africanos e asiáticos - encerrasse uma era e outra, diferente e destacada daquela anterior, se iniciasse. Finda-se o colonialismo, sobra e continua a colonialidade como modo de significação e de relação de poder, de saber, de ser e de gênero (LUGONES, 2014). É nessa diferença sobre 
linguagens atribuídas a corpos para usar o corpo como categoria jurídica de análise e, com esse corpo, compreender o humano como "em processo de", exigindo-nos compromisso com "dignidades" produzidas a partir da multiplicidade da "pessoa". Depois, usa duas categorias jurídico-constitucionais para rediscutir essa entrada nos marcos do gênero e da raça - e das múltiplas corporalidades: "dignidade da pessoa humana e povo".

Assim, pergunto-me como interpretar o Direito de modo a permitir uma narrativa expansiva sobre o humano? Como podem contribuir a Filosofia do Direito, da Justiça e da Constituição para essa compreensão expansiva do humano para além da colonialidade do ser, do gênero e da raça? E, especialmente, o contrário: como as teorias do gênero e da colonialidade podem contribuir para uma narrativa expansiva e não universalizante? Com foco na crítica do uso de universalismos e abstrações para falar de humano, a proposta não se funda em criar categorias, estruturas ou teorias que possam incluir todos em um conceito de "humano" (isso é tarefa fadada ao fracasso, já de saída), mas em pensar categorias e teorias que possam ser e estejam sempre sujeitas à interpretação (e à temporalidade) para permitir novas possibilidades, para ser, assim, expansiva.

Ao mesmo tempo, a tarefa não pode se perder em um imaginário, fundar-se em uma utopia meramente especulativa. Isso significa que não se fará nenhuma defesa, por exemplo, de "abolição do gênero" como o caminho para a expansão do vivível do humano, seja por ser uma proposta como essa inverossímil, seja porque categorizações existem e sempre existirão e pretender eliminá-la desde um lugar teórico pode significar fechar os olhos a essa realidade e abandonar aquelas pessoas excluídas do inteligível. Mesmo uma teoria que se pretenda universal e abrangente por abolir o gênero continuará a produzir o seu abjeto, o seu fora da norma, o

continuidade e, ainda, considerando as proximidades histórico-geográficas, que as teorias decoloniais se adequam melhor ao presente trabalho. Como, então, um "padrão de poder que estrutura o sistema mundo moderno", tomo aqui a colonialidade como a cadeia histórica de significados que organiza, hierarquizando a partir da racialização, os modos de "trabalho, subjetividade, conhecimento, lugares e seres humanos do planeta" (RESTREPO; ROJAS, 2010, p. 16). 
seu campo de ininteligibilidade. Esse o ponto de partida para o trabalho: a crítica não se situa nos pedidos de reconhecimento de diferentes identidades, nas dificuldades desses pleitos e na proposição de novos modos de fazer política identitária. Como a proposta do trabalho é a de uma teoria expansiva do humano no direito, a questão está centrada na dissolução ou inadmissibilidade de concepções meramente impositivas - colonizadoras ou na interpretação expansiva dessas normas. Isso não significa abandonar completamente o uso, por exemplo, de categorias como "mulher", mas compreender que até mesmo uma categoria como essa deve ser passível de abertura e estar sujeita à interpretação. Significa reconhecer que as normas de gênero da matriz ou ideal branco cis-heteroconforme (MAGALHÃES GOMES, 2017c) criam um ideal de completude e coerência internas e que, por óbvio, como ideal que é, não existe e é inalcançável.

Para tentar responder a essas questões, com a articulação performatividade-decolonialidade, o caminho é aproximar dois termos do texto constitucional que podem permitir essa entrada expansiva do humano: "povo e dignidade da pessoa humana". Desenvolvi, anteriormente, uma crítica desses dois termos nos mesmos marcos aqui apontados (MAGALHÃES GOMES, 2019; 2018) e por isso remeto o leitor a esses textos, uma vez que o que aqui será feito corresponde a uma junção das críticas feitas a esses institutos jurídico-constitucionais para, agora, apresentar uma leitura expansiva de ambos de um modo articulado um com o outro.

Mas, por que escolhi o termo "expansiva" ou "expansividade"? A escolha passa por pensar que para mudar essa teorização sobre o humano seria necessário encarar a relação universalismos/individualismos - aqui representados em povo e pessoa humana - de modo diferente que não a oposição radical nem a fusão de um em outro, mas que ficasse na fronteira entre os dois, usando-a ao mesmo tempo como lugar de comunicação receptiva, aberta e circulante e como, da figura da linguagem comum, "expansão de fronteiras": trabalhar na fronteira não é pretender torná-la tudo o que existe nem suprimi-la, mas saber que nela pode estar o que os extremos e seus usos escondem. 
Antes de seguir, quero anotar que este trabalho se insere em um compromisso com a teoria, assim como pretende ser uma teoria comprometida. Isso significa que não há adesão ou compromisso com essa ou aquela teoria, mas que, centrada no compromisso com a expansão das vidas possíveis, com aqueles que no marco da colonialidade não contam como humano, procuro na teoria o que possa expandir os limites do vivível. Assim, se faço movimentos entre a teoria da performatividade e a teoria decolonial que talvez não fossem "autorizados" por autoras dessas linhas, esses movimentos dão-se autoridade à medida em que possam revelar uma autoria comprometida. Ao mesmo tempo, acredito que, como a teoria define quem conta ou não como ser humano, tomá-la como espaço de compromisso, dissenso e luta é fundamental para discutir esses limites. Escolho trabalhar com teoria e com teoria compromissada pela necessidade de descentramento de poder/saber objetos da colonialidade que não nos permite - daqui da margem e das marginalidades de gênero e de raça que produz corpos fora da norma - questionar a norma. Melhor dito: produzir filosofia do direito é produzir teoria e, para tanto, a colonialidade do poder e do saber não nos permite dizer o que é o direito, já dito por europeus e norte-americanos. Por que não podemos daqui, da nossa condição de latino-americanos, dizê-lo desde a margem? Aqueles que ocupam lugares de privilégio, aqueles que se encaixam no molde do universal digno, são aqueles que produzem os discursos da norma e da normalidade, são aqueles que produzem os discursos que buscam impor a ideia de uma estabilidade e completude humanas, que buscam esconder nossa condição de relacionalidade, precariedade, fracasso e incompletude. A forma hegemônica de compreensão da cadeia dos direitos humanos - e por consequência dos direitos fundamentais - está assentada na ideia do humano universal completo e estável, do humano livre. Livre como autônomo e independente, dissociado do aspecto relacional -, que está na própria noção de autonomia e agência, nos mostrando que não existe autonomia nem agência sem que as nossas possibilidades de relacionalidade assim nos permitam. 


\section{Corpo e humano "em processo de"}

Em dois outros momentos, elaborei argumentos a respeito dos institutos jurídico-constitucionais que aqui utilizo - povo e dignidade da pessoa humana - sob uma perspectiva performativa-decolonial, relendo-os sob os marcos da raça e do gênero. O propósito a partir desse momento é pensar como as formas de teorizar sobre o corpo e o direito me permitirão fazer de outro modo o "humano" entrar no "jurídico" por meio das categorias escolhidas. Como referido na introdução, trabalhar o humano no jurídico é oscilar entre dois pontos: a universalidade e a individualidade. Em direitos humanos e fundamentais, especialmente, a teorização toma o "humano" como categoria universal sob consenso para estabelecer que direitos pertenceriam a esse. Toma o universal como parâmetro para lidar com individualidades. O que acontece quando as corporeidades e as linguagens de gênero e de raça são trazidas para o meio dessa oposição? Como construir uma outra narrativa sobre o humano, uma narrativa expansiva que não realize homogeneizações universalizantes que eliminam diferenças? Para encontrar o caminho dessa fronteira de expansividade, sigo duas lições.

Uma de Viviane Vergueiro, para quem as pretensões de definição objetiva a respeito das identidades de gênero trans e travesti são infrutíferas e que devemos nos mover na "busca de conhecimentos que denunciem a necessidade urgente desta recusa" (2015, p. 181). Considerando que a classificação que vem de um "olhar de fora" é parte da colonialidade e que essa guarda como dicotomia fundante a oposição humanos/não humanos, a tarefa por ela proposta pode nos indicar um caminho expansivo. Por isso, proponho aprender com as travestilidades a contenção desse impulso classificador que desumaniza, aprender que falar de humano deve abandonar esse "olhar colonizador". Outra de Butler, segundo quem a mudança pode acontecer quando quem não foi incluído nos termos do performativo passa a usá-los, com novos significados. A autora cita, por exemplo, como o uso de termos como "justiça" ou "democracia" podem ir ganhando outros significados quando tomados por aqueles comumente 
excluídos ou violados pelos usos dominantes dos termos, quanto esses excluídos passam a se apropriar do discurso autorizado e que essa apropriação é um potencial lugar da ressignificação subversiva desse discurso (BUTLER 1997a, p. 158, tradução nossa) ${ }^{6}$.

A partir disso, então, e tendo em questão, ainda, que nos tornamos sujeitos dentro de um campo de linguagens que não escolhemos e não são nossas e que, assim, a subjetivação é um processo auto e heteroreferenciado, começo realizando uma leitura entre povos e pessoas: uma aproximação - que não é fusão - entre as categorias de "povo" e "dignidade da pessoa humana" que possa atender a proposta para que as pessoas excluídas desses conceitos na matriz dominante possam deles se utilizar, que possam se apropriar dos termos que antes as excluíram. Certamente isso não resolverá as dificuldades interpretativas das pessoas intérpretes oficiais da norma jurídica, não resolverá o conflito entre democracia e direitos fundamentais e os constrangimentos impostos a essas pessoas nos momentos de decisão. Que eu tenha escolhido, porém, me mover de fora para dentro, falar com esses de fora, não significa que essa narrativa não possa servir também às intérpretes oficiais.

E é com essas duas lições em mente que apresento minha proposta. Antes, algumas considerações: ao analisarmos a teoria hegemônica sobre

6 Do original: Indeed, I would argue that it is precisely the expropriability of the dominant, "authorized" discourse that constitutes one potential site of its subversive resignification. What happens, for instance, when those who have been denied the social power to claim "freedom" or "democracy" appropriate those terms from the dominant discourse and rework or resignify those highly cathected terms to rally a political movement? If the performative must compel collective recognition in order to work, must it compel only those kinds of recognition that are already institutionalized, or can it also compel a critical perspective on existing institutions? What is the performative power of claiming an entitlement to those terms- "justice" "democracy"that have been articulated to exclude the ones who now claim that entitlement? What is the performative power of calling for freedom or the end to racism precisely when the one or the "we" who calls has been radically disenfranchised from making such a call, when the "we" who makes the call reterritorializes the term from its operation within dominant discourse precisely in order to counter the effects of that group's marginalization? Or, equally important, what is the performative power of appropriating the very terms by which one has been abused in order to deplete the term of its degradation or to derive an affirmation from that degradation, rallying under the sign of "queer" or revaluing affirmatively the category of "black" or of "women"? 
a dignidade da pessoa humana, encontramos "um sujeito que possui em si um valor intrínseco, por ser humano; autônomo como sujeito racional que, por vontade livre dá a si sua própria lei que, por sua vez, sendo resultado de uma atividade racional, é universalizável; que necessita de um mínimo material para sobreviver" (MAGALHÃES GOMES, 2019). Ocorre, contudo, que esse sujeito não existe. É o sujeito moderno, o sujeito construído a partir de um lugar situado, mas que se pretende um modelo universal como se neutro fosse, escondendo essa sua condição de situado. Quando lemos tal noção de sujeito (ou de pessoa, ou de indivíduo), sob as lentes do gênero e da raça ou sob um marco teórico performativo-decolonial, percebemos que esse sujeito como o universal, que serve de ideal a pensar o humano, não existe. $E$, como diz Costa Douzinas, ou ele "é muito abstrato para ser real, ou muito concreto para ser universal" (DOUZINAS, 2009, p. 113).

Mais do que isso: esse sujeito insular e autônomo que dá a si mesmo "a lei" não só não existe, como não nos deve servir como ideal. Descorporificado, falsamente neutro, ele se transforma em um modelo que exige de nós um "estar diante da lei" - aqui, do Direito - também de modo descorporificado para que se possa pensar em justiça, possa se decidir sobre direitos, possam ser aplicados os direitos fundamentais em um Estado Democrático de Direito. O que ocorre, contudo, é que nossos pleitos nascem de uma vida corporificada, nascem de relações e contextos situados. Esse modelo, portanto, nos exige ser menos, apresentarmo-nos como menores ou despidos de tanto do que nos constitui e, como aponta Douzinas, o sujeito é apenas uma caricatura da pessoa (2009, p. 245). A realidade é que o sujeito é sujeito da e na lei, como sujeito e sujeitado7. E

\footnotetext{
7 "A noção de performativo, nesse caminhar, serve, então, também para refletirmos essa subjetivação corporificada, a nossa formação como sujeitos. Pois o sujeito é apenas sujeito na e da lei, como sujeito e sujeitado, lei aqui como linguagem, como norma social, psicanalítica, moral e jurídica, como a linguagem que normatiza os corpos, o que significa que o processo de subjetivação é um processo corporificado (BUTLER, 2015a, p. 236). Nos tornamos diante de normas que não nos demos e essas normas são de raça, sexo e gênero, são normas de linguagens sobre os corpos. O processo de subjetivação é, então, sempre um processo de violência, um processo que é externo e interno. Somos formados/forjados na violência, mediante a instauração de normas que nos são impostas. Remetemos o leitor, para o desenvolvimento dessas,
} 
aí entra a proposta deste texto: a interpretação do humano no Direito, no lugar de buscar conceituar quem são os sujeitos possíveis ou usar o modelo de sujeito do qual falei acima, deve passar por entregar àqueles excluídos da lei a condição de darem a si uma lei, o que significará darem a lei que os constituem como sujeitos autônomos pública e privadamente, ou seja, "parte do povo" e "pessoa humana digna" ao mesmo tempo. Para fazer isso, defendo que temos que "aprender com as travestilidades".

Viviane Vergueiro (2015) pede que recusemos urgentemente a pretensão de definir as travestis e transexuais: esse impulso classificatório, essa urgência em definir "o que" ou quem é o outro, essa categorização "de fora" é prática comum do humano, no entanto, a transformação dessa categorização pelo olhar externo em norma, em parâmetro de civilidade e relacionalidade é a nota da colonialidade, a atividade do privilégio, do dominante, do "sujeito racional". Como em uma relação sujeito-objeto, aquele que define "o que é" o outro toma-o como objeto de conhecimento, como lugar em que se deposita um significado a partir de fora. Ao contrário de uma identidade ou sentido autodeclarado, o significado conferido nesse processo externo é confinante e autoritário. Ocorre, no entanto, que objetos não são, e as pessoas se constituem e são constituídas dentro e a partir dessas relações em que a linguagem externa os aponta. A categorização como uma relação sujeito-objeto se constitui como violência e pressupõe o olhar desumanizador que percorre os corpos nessa urgência classificatória que traz os sujeitos ao "ser". Ao mesmo tempo, no entanto, promove a operação de ocultar o caráter performativo dessa empreitada e o resultado mais comum é a fixação da ideia de que as categorias que utilizamos para dar nomes aos corpos são apenas escolhas linguísticas para realizar uma descrição da realidade: o corpo é natureza, o corpo é matéria e apenas o nomeamos.

Luma Nogueira de Andrade (2015) diz que ao olharmos para o processo de transformação "sem fim" dos corpos das travestis, percebemos

ideias ao artigo "Os sujeitos do performativo jurídico - relendo a dignidade da pessoa humana nos marcos de gênero e raça" (MAGALHÃES GOMES, 2019). 
que todas as pessoas vivem nesse modo de "fazer" e "falar" os próprios corpos, repetida e continuamente. Essas duas lições são questões fundamentais quando falamos sobre sexo, gênero e raça: não conhecemos um corpo como tela em branco e todas, em alguma medida, somos a vivência de corpos modificados, transformados, corpos "em processo de". Esses processos, contudo, podem ganhar ou não legitimidade na medida em que estejam ou não inseridos na linguagem da colonialidade que articula sexo, gênero e raça, atribuindo ou não humanidade aos corpos a partir de um ideal branco e cis-heteroconforme.

Tomemos a vivência, a experiência e os discursos sobre as identidades travesti - ou travestilidades (PELÚCIO, 2009, p. 27-28) em razão do termo apontar "para a multiplicidade dessas vivências ligadas à construção e desconstrução dos corpos" - no Brasil e sobre como o tratamento e a violência contra essas identidades revelam essa construção do corpo na colonialidade brasileira, "esse olhar de fora", como atividade do privilégio e do impulso classificador: "dizer quem é o outro, definir quem é o outro". Esse é o olhar que constantemente se lança às travestis, tanto como parte da discriminação e da violência a que estão submetidas, quanto como parte da escrita dos que "estudam" as travestis, como parece ser o caso de algumas das mais comumente citadas etnografias sobre travestis no País ${ }^{8}$. Como diz Luma Nogueira de Andrade, parece haver, com as definições em trabalhos como o de Don Kulick (2008), uma generalização de um ideal de "travesti nacional" (2015, p. 110). Mesmo a respeito da pesquisa de Marcos Benedetti, que sustenta em seu trabalho que não fará uma definição categórica das travestis (2005, p. 17), Andrade encontra - o que me parece acertado - alguma tentativa de definir as travestis ainda que de modo localizado (2015, p. 109). Viviane Vergueiro é enfática sobre a necessidade de recusa desse impulso em definir ''objetivamente' quem

\footnotetext{
8 Dentre elas estão os trabalhos de Kulick (2008), Silva (1993 e 2007) e Benedetti (2005). Recentemente, contudo, pesquisas com abordagens queer, feminista, de gênero ou pesquisas feitas por travestis com e sobre travestis têm fugido desse impulso classificatório, como é o caso dos trabalhos de Andrade (2015) e Vergueiro (2015).
} 
'é' travesti e transexual" (2016, p. 118) e pergunta "o que se ganha, afinal, com a batida análise sobre 'quem é travesti, quem é [mulher] transexual', para além do desenvolvimento de uma mirada que será sempre insuficiente em relação aos complexos autorreconhecimentos de identidades de gênero?". Mirada que chama de ciscolonial (VERGUEIRO, 2016, p. 111).

Quando, então, Larissa Pelúcio também define as travestis como "pessoas que se entendem como homens que gostam de se relacionar sexual e afetivamente com outros homens, mas que para tanto procuram inserir em seus corpos símbolos do que é socialmente tido como próprio do feminino" (2005, p. 97-98,) e, em sequência, fala que essas não desejam "extirpar sua genitália, com a qual, geralmente, convivem sem grandes conflitos" (2009, p. 44), há uma confusão sobre sexo, gênero e sexualidade, como alertou Andrade e uma tentativa de diferenciar travestis e mulheres trans, como alertou Vergueiro. Travestis, assim como mulheres trans, assim como mulheres cis, podem desejar ou se relacionar com homens, mulheres ou pessoas não binárias. A diferença, para Andrade, é que "as travestis, por outro lado, não são, isoladamente, homens ou mulheres, são homens e mulheres, não existe uma fronteira fixa, podem desejar e sentir afetos por homens e por mulheres, por travestis e por transexuais" (2015, p. 116, grifo nosso). O que emerge dessa crítica de Andrade é que, enquanto as próprias travestis por ela pesquisadas destacam em sua identidade elementos que fogem a questões de sexo, gênero ou prostituição, aquelas etnografias citadas buscam nesses elementos o centro para formular definições ou guiar os caminhos de pesquisa. Como narra Andrade "as travestis que pesquisei [...] se negam a comercializar seus corpos" (2015, p. 110) e definem a identidade com termos como "evolução", "novo ser", alguém "ágil, inteligente, calma e batalhadora" e para elas, como aponta a autora, travesti "tem outra conotação, outro contexto de existência", como encontrado nas falas de Bela e Ana por ela entrevistadas (ANDRADE, 2015, p. 113). Quando se referem a sexo, falam de algo diverso do sexo anatômico, para ela, um "sexo imaterial, subjetivo, que se materializa no corpo através das transformações biológicas e 
culturais" (ANDRADE, 2015, p. 115). Ou seja, não é que as travestilidades não sejam "também" identidades de sexo e gênero, mas elas não são "apenas" isso ou sempre organizadas em torno disso e, ainda, não é que as travestilidades não se relacionem com uma identidade feminina, mas, novamente, nem são apenas isso, nem organizadas apenas em torno disso e apresentam fluidez, trânsitos e transformações de corpos, sexo, gênero e sexualidade: não são isoladamente um ou outro, mas podem ser um ou outro, um e outro. E enquanto se quer encaixar as travestilidades em alguma narrativa "objetiva" ou "coerente", as próprias usam e vivem as suas identidades para além do sexo, do gênero ou da sexualidade fixa.

Mesmo que, então, discordando da definição dada por Pelúcio, o seu trabalho traz um ponto que me parece fundamental para discutir as identidades travesti ou travestilidades como ela nomeia: ser travesti é algo "continuado e sem fim", um "processo", uma construção do corpo que nunca se encerra (2005, p. 98). Pensando nesse corpo, identidade, subjetividade como "em processo de", Andrade diz que existem "travestis de todos os sexos, gêneros e sexualidades que buscam através de diferentes técnicas, como cirurgias plásticas, hormonização, observação, entre outras, se adequar corporalmente ao que consideram beleza do outro" (2015, p. 117). E, mais à frente, completa:

A frase - Em cada homem existe um pouco de mulher e em cada mulher existe um pouco de homem não deveria nos surpreender, pois encaminhando tal discussão até para o olhar da biologia se constata que homens produzem hormônio masculino (testosterona) e feminino (progesterona), assim como as mulheres. Com esta percepção, a oposição entre feminino e masculino se liquefaz, escapando de qualquer forma de controle. Neste contexto, não apenas travestis vivem a multiplicidade de poder ser homem e mulher corporalmente, mas todos os humanos (ANDRADE, 2015, p. 257).

Há travestis que querem realizar a cirurgia de transgenitalização. Há transexuais que não desejam realizá-la. Há travestis que se prostituem, há 
as que não. E como vamos definir o que é a identidade travesti? Que façamos essa pergunta diz mais e apenas sobre nós. Além disso, fazendo essa pergunta, perdemos outro componente fundamental dessas identidades: em diversos contextos e momentos, elas são também e fortemente identidades políticas e de resistência, que nos marcos de gênero, raça e classe são carreadas por uma identidade de luta e resistência contra a discriminação do trabalho sexual, a discriminação de classe, o racismo, a transfobia e a misoginia. Não quero e nem vou reivindicar que "somos todas travesti", esvaziando as travestilidades e invisibilizando a identidade e a violência a que são submetidas. Faço essas elaborações, junto com as autoras referidas, e guardo essas ideias sobre travestilidade e essa última visão de Andrade apresentada acima para retomá-la ao final, para refletir como a relação da matriz branca e cis-heteroconforme com as travestis deve ser tomada não para olhar para elas, ou para falar delas ou por elas, mas para olhar para todos os corpos, identificações e linguagens da colonialidade.

Assim, não quero falar em aprender com as travestilidades para usá-las como exemplo de como elas abalam, deslocam ou questionam o ideal. Aprender com as travestilidades é aprender que se pararmos de lançar às travestis um olhar que busca ou julga "corpos e gêneros 'curiosos' e 'exóticos'” (VERGUEIRO, 2015, p. 119) e voltarmos todas o olhar para nossos corpos, talvez possamos perceber aquilo que falei acima e que é parte do comentário de Andrade: somos todos corpos "em processo de" e que produzimos um ideal de completude que é aparente, talvez para justamente escondermos ou recusarmos nossa própria multiplicidade. Aprender com as travestilidades, aqui, quer significar reivindicar que, lendo e ouvindo as suas histórias e trabalhos, possamos olhar para os corpos e humanidades múltiplas, escondidas ou violentadas pela colonialidade e pelo seu sujeito aparentemente completo, pronto e autônomo e neles enxergar que são todas corpos e humanidades "em processo de". Isso será feito não para equalizar os corpos caindo em um discurso de igualdade liberal, mas para, identificando o componente de "processo" como linguístico e corporal, perceber que as linguagens que usamos 
para significar os corpos podem ou funcionar como simples repetição e confirmação do ideal daquele sujeito moderno ou trazer para o campo jurídico que, apesar de sermos todos em processo, a violência da subjetivação na lei confere legitimidade a uns mais do que a outros. Isso talvez porque uns consigam, por inseridos mais próximos dos marcos do ideal (homens brancos, pessoas cis, pessoas heteroconformes), realizar seus "processos" de modo a esconder ou recusar sua conflitualidade interna e se encaixar no molde que a colonialidade nos deu.

Para isso, então, essa recusa da pretensão de definição que sigo com Vergueiro é a recusa da colonialidade e, com ela, passamos a refletir que, no lugar de "reconhecimento", reivindica-se conferir o respeito e o direito à autodeclaração - seja essa de raça, etnia, gênero ou sexualidade-e a autodeterminação. Autodeterminação e autodeclaração podem ser ferramentas fundamentais de uma performatividade subversiva para uma teoria expansiva, uma performatividade que desfaça a matriz. Com elas, deslocamos uma parte central da linguagem da colonialidade: a criação de categorias por aquele que guarda o lugar do privilégio para definir o outro.

Isso pode ganhar contornos relevantes em vários casos, dos quais pontuo dois: primeiro, no tratamento das questões de gênero internas aos povos indígenas. No lugar de soluções que tomem a "defesa das mulheres" ou o "feminismo" ou o "gênero" ou o "queer" como parâmetros para ler o conflito e encontrar soluções ou políticas públicas, Lívia Gimenes Dias da Fonseca defende que é preciso encontrar caminhos dialogais de um feminismo decolonial que "deve incorporar a capacidade de respeitarmos os processos coletivos de cada grupo de mulheres (2016, p. 146) o que passa por garantir "seu direito à autodeterminação que significa reconhecer as suas formas de resolução de conflitos internos ou inclusive de recriá-las de forma a permitir a expulsão dos colonialismos e dos patriarcalismos presentes internamente" (2016, p. 146). Com isso, não se corre o risco de, ao se discutir questões de gênero como a violência doméstica, agir produzindo uma destruição ou enfraquecimento do tecido comunitário (SEGATO, 2012, p. 110), fundamental para a vida, a identidade e, a rela- 
cionalidade dos povos indígenas e que é resistência à violência racista da colonialidade. Resistência essa que é estampada na narrativa de Rita Segato sobre o pedido de mulheres indígenas de que

[...] durante a formulação das reivindicações de gênero, pensar e sugerir maneiras de modificar os costumes que as prejudicavam, evitando que essas modificações alcançassem a cultura como um todo. Em outras palavras, o que se apresentou como o grande desafio para as culturas fragilizadas pelo contato com o Ocidente foi a necessidade de implementar estratégias de transformação de alguns costumes, preservando o contexto de continuidade cultural (2006, p. 210).

Essa recusa da definição do outro também é elemento fundamental quando se fala em gênero das pessoas travestis, trans e intersexuais. Considerando que não conhecemos os corpos como naturais, puros, destituídos de sentido, mas sim sempre como já corpos na linguagem, e que essa linguagem é a que articula sexo-gênero-raça e que o processo de subjetivação é um processo de violência corporificada, reivindicar a autodeclaração não é defender que o sujeito "escolha" - ainda que o elemento escolha esteja, claro, presente. Isso porque essa escolha, como escolha livre, original e inteiramente autodeterminada não existe. A reivindicação está virada para o componente normativo: se não escoIhemos a linguagem na qual estamos inseridos, que sejamos autorizados a "usar" essa linguagem tanto para que, individualmente, possamos lidar com a violência, quanto para que esse uso possa promover a diminuição da violência normativa. Explico um pouco mais: garantir que as pessoas possam autodefinir-se em termos de sua corporalidade - de sexo e de gênero - significa, em última instância, garantir que possam inscrever a sua própria humanidade e a sua dignidade. Não se trata apenas de "reconhecer" como "direito da personalidade", mas de permitir que essas múltiplas formas de usar e de fazer a linguagem sobre o corpo, sobre as identidades de sexo e de gênero, sobre o nome - sobre as próprias 
formas de categorização, portanto - "possam mudar as normas de reconhecimento". Isso pode impactar a forma de produção política e de identificação dentro do Direito: o performativo jurídico, dentro dessa forma de saber e de poder da colonialidade, cria a política de reconhecimento na estrutura moderna de binarismos, que só consegue pensar em igualdade e diferença, ou seja, em um outro que é diferente de mim e precisa ser assim reconhecido ou em um outro que precisa ter direitos iguais aos que possuo. O pensamento moderno não consegue codificar a possibilidade, o múltiplo. Talvez porque ela seja mesmo incodificável, o que não é de todo ruim, mas talvez mesmo porque nele não haja lugar para tal. A autodeclaração e a autodeterminação podem ser instrumentos de uma outra operação em que o múltiplo mostra que a concessão de direitos não precisa ser essa relação de dois. Para isso, contudo, ela tem que ser tomada não apenas como elemento para o reconhecimento dentro da teoria da dignidade da pessoa humana, mas também como elemento que desestabilize o povo universal e faça nele conter povos que possam produzir a normatividade sobre diversos modos de autonomia.

Isso irá implicar que a essa autodeterminação e autodeclaração não se poderá impor critérios externos de definição, como, por exemplo, no caso do tratamento jurídico das identidades travestis e transexuais, aqueles que passam por uma patologização das identidades referidas ${ }^{9}$. A luta pelo direito à identidade de gênero despatologizada é "um dos aspectos políticos centrais da ação coletiva relacionada às pessoas transgênero" como uma luta pelo direito "de poderem se nomear, de serem autônomas para falarem de si mesmas" (JESUS, 2012). Essa imposição de "barreiras jurídico-legais para o reconhecimento de um [as pessoas trans] é parte do processo da construção jurídica da naturalidade do outro [as pessoas cis],

\footnotetext{
9 O direito à autodeclaração de pessoas transexuais, transgêneros e travestis foi reconhecido pelo Supremo Tribunal Federal por meio do provimento da Ação Direta de Inconstitucionalidade $n$. 4275. BRASIL, Supremo Tribunal Federal. Ação Direta de Inconstitucionalidade. ADI 4275. Tribunal Pleno. Relator Ministro Marco Aurélio, 2018b. Disponível em: http://www.stf.jus.br/portal/geral/ verPdfPaginado.asp?id=400211\&tipo=TP\&descricao=ADI\%2F4275. Acesso em: 10 out. 2018.
} 
reforçando, assim, a lógica de apagamento e marginalização das pessoas trans" (COACCl, 2013, p. 59) ${ }^{10}$ e, mais do que isso, cumpre a operação de distribuir de modo diferencial a humanidade a pessoas cis - como se naturalmente já a tivessem - e a pessoas trans - que deveriam ser submetidas a testes, exames, comprovações para a terem reconhecida"1.

Aprender com as travestilidades também é aprender a usar a linguagem performativa nela inscrevendo novos significados como parte do processo de autodeclaração. Como apresenta Larissa Pelúcio, o termo passou a ser usado por travestis, em especial ligadas ao movimento social,

numa tentativa de ressignificar o sentido das palavras 'travestismo' e 'travesti'. Um processo que se pluraliza, daí o 's' que precisa ser acrescentado à noção ainda incipiente de 'travestilidade', enquanto reflexão e tentativa teórica de se ir mais além do que o senso comum tem se permitido (2009, p. 43).

Essas considerações nos trazem a dizer que não há sujeito completo, pronto: há um humano "em processo de" e ser sujeito nunca chega. Há um contínuo de performatividade, há uma iterabilidade de reinscrição e/ ou ruptura da norma ${ }^{12}$. Há um fracasso. O humano é uma experiência de fracasso e incompletude, uma experiência que é processo e que não se completa. Do mesmo modo, não há nem um voluntarismo - como uma escolha - nem um determinismo das normas que o formam. Somos a différance $^{13}$ na inscrição da norma, que instaura temporariamente uma

\footnotetext{
10 Coacci vê nesses critérios uma sexopolítica que implica, também, o controle da população e a negativa de direitos sexuais e reprodutivos (Idem, p. 59).

"Também sobre autodeclaração de gênero ver Antidiscriminação e travestilidade no Brasil (RESADORI, 2016).

12 A esse respeito, a leitura de Excitable Speech (BUTLER, 1997a).

13 Como muitos dos conceitos de Jacques Derrida, a différance rejeita definições. A différance não é. Opera. Performa. Funciona em um movimento duplo de diferir: diferir como estabelecer diferenças - decidir, escolher, portanto - e diferir como adiar, prorrogar, deixar para um momento posterior. Comprometida com a multiplicidade de sentidos que constituem a realidade (e que ela constitui), não há sentido pronto ou verdade nessa operação. Das palavras do autor:
} 
diferença ao mesmo tempo que a adia. Nem voluntarismo nem determinismo. Somos em processo, submetidos ao (à violência do) nosso relacionar. Dependemos do outro, dependemos (ou estamos sujeitos) das condições e normas criadas pelo outro e da atribuição diferenciada dessas condições. Somos todos a possibilidade de violência.

Quando se coloca o sujeito da modernidade como parâmetro para o humano, o sujeito aos moldes kantianos, aquele que constitui a concepção dominante da dignidade da pessoa humana no Direito brasileiro, o direito se perde em como adaptar as questões da corporalidade ao ideal de autonomia descorporificada. Caímos em um lugar sem fim e repetimos a dominação razão-corpo própria da colonialidade (MALDONADO-TORRES, 2007). Se, no entanto, não usamos de um ideal regulativo e abrimo-nos para a interpelação mútua, para o reconhecimento da formação da autonomia na dependência ${ }^{14}$, precisaremos de um processo sem fim de inscrições de "dignidades" que não pode ser a de um julgador que se pauta pelo ideal, mas de seres mutuamente interpelados que precisam se abrir e ouvir, comprometendo-se com a construção dessa humanidade que é relacional. Teorizar o humano no Direito, assim, passa a ser teorizar pelos que "eram" corpo'5: no lugar de um compromisso com um ideal de sujeito, o compromisso em pensar "que corpos importam e por quê?" (BUTLER, 1993, p. xi-xii, tradução nossa). E questionar que corpos importam é ques-

\footnotetext{
"Diferir, nesse sentido é temporizar, é recorrer, consciente ou inconscientemente, à mediação temporal e temporizada de um desvio que suspende a consumação e a suspensão do 'desejo' ou da 'vontade', realizando-o de fato de um modo que lhe anula ou modera o efeito. [...] O outro sentido de diferir é o mais comum e o mais facilmente identificável: não ser idêntico, ser outro, discernível etc. Tratando-se de diferentes de diferen(te)/(do)s, palavra que, portanto, poderemos escrever como quisermos, com um t ou com um d, quer esteja em questão a alteridade de dissemelhança, quer a alteridade de alegria e de polêmica, é sem dúvida necessário que entre os elementos outros se produzam, ativamente, dinamicamente, e com uma certa perseverança na repetição, intervalo, distância, espaçamento" (DERRIDA, 1991, p. 39).

14 A esse respeito, ver Antropologia e direitos humanos: alteridade e ética no movimento de expansão dos direitos universais (SEGATO, 2006) e The Psychic Life of Power: Theories in Subjection (BUTLER, 1997b)

15 Sobre os sujeitos que são vistos como apenas corpos, Justice and the Politics of Difference (YOUNG, 2011)
} 
tionar quem conta como humano, o compromisso com o que os excluídos na norma, os condenados, os abjetos têm para dizer e performar sobre o humano. Passa a ser teorizar para permitir Têmis performar.

Para evitar, contudo, que isso se transforme em uma equalização dos sujeitos como se todas as violências fossem as mesmas é que (i) as corporalidades e suas linguagens devem ser fonte e lugar da teoria; (ii) é preciso não apenas utilizar a autodeclaração e autodeterminação como forma de reconhecimento, mas também teorizar para que os que o fazem não sejam apenas sujeitos de direito, mas também sujeitos do direito: que possam ser ao mesmo tempo parte do que e de quem concede ou cria direitos. Para isso, passo a articular as duas categorias aqui utilizadas.

\section{Entre pessoas e povos: a proposta da expansividade}

Parece haver uma ideia de que entre universalizações e particularismos há uma polaridade irresolvível e que, enquanto a primeira deve ser sempre abstrata, só à segunda caberá preencher de conteúdos historicamente enraizados (NASCIMENTO, 2003, p. 39). Esse embate universalismo/ individualismo, que está no centro da discussão sobre Direito e Justiça, ganha representações como o embate entre democracia e direitos fundamentais, poder constituído e poder constituinte, entre autonomia privada e autonomia pública; mas a sua existência, aqui, não é problema. Estar na fronteira é o que defendo: não há nele consenso possível, mas o exercício de um dissenso expansivo. Do mesmo modo, não há nem é possível, consenso sobre o que constitui "pessoa humana" ou "povo" ou "homens e mulheres" e nem há consenso sobre que direitos são necessários para a garantia da dignidade - especialmente se considerados que esses direitos são, na sua história, instituídos a partir do binário masculino/feminino no marco da raça. Minha escrita sobre estar na fronteira, portanto, segue o propósito de um constitucionalismo radical, conforme Vera Karam de Chueiri. Isso porque, quando se trata de falar em direito como ato de fala performativo e se trata de cuidar da interpretação de direitos funda- 
mentais, o intérprete é mais do que um sujeito que realiza essa atividade de conflito e compromisso. Há uma necessária "responsabilidade". Sob a leitura performativa aqui feita, o constitucionalismo não deve apenas guardar compromisso com o conflito ele "é" o próprio conflito, ele "é" a tensão (CHUEIRI, 2013, p. 29). Constituição como performatividade é Constituição como herança, como exercício do presente e como futuro: é essa a ética que se carreia com a différance, que aqui utilizo como exercício de estabelecer e adiar sentidos. Uma Constituição, portanto, radical, "que não se conforma aos mecanismos liberais de mútua negociação entre os poderes constituídos, arriscando-se a ser mais do que isso, ou seja, objeto e sujeito da política democrática" (CHUEIRI, 2013, p. 29), o que, portanto, não significa entronizar o momento fundacional como esgotamento de sentido e do exercício do poder constituinte. Ler desse modo a Constituição significará que ela "não se deixa reduzir ao constituído, mas nela retém o poder constituinte e desta forma nos constitui, radicalmente, como comunidade política" (CHUEIRI, 2013, p. 26). Nesse sentido, quando afirmo a performatividade do Direito e, em especial, do texto constitucional, isso implica que, "o constitucionalismo, ao invés de frear o poder constituinte, o exibe, o expõe e o reafirma quando garante, protege e renova os compromissos democráticos, sobretudo através da realização da Constituição" (CHUEIRI, 2013, p. 32) o que exige compromisso, responsabilização, ética, "ação política no presente", uma percepção de que jurídico e político não se fundem nem se recusam, mas devem ser articulados em uma "paradoxal busca, em simultâneo, de abertura e fechamento" (KOZICKI, 2004, p. 148, grifo nosso), que eu prefiro chamar de fronteira a expandir. Essa fronteira, essa abertura, traz conflito e compromisso, tensão e responsabilização. Por isso, falar do humano no jurídico trata de tensionar, entre o Eu e o Você, entre o falante e os destinatários, entre o universal e o individual, aquele que dá a norma - povo - e aqueles que vivem e recebem a norma - pessoa humana digna.

Quando tomamos, contudo, a categoria universal "povo" como um performativo (MAGALHÃES GOMES, 2018), diante da categoria particular 
"dignidade da pessoa humana", a construção de pluriversalidades pode ser um passo possível em que um pode funcionar, circularmente, como fronteira do outro: a multiplicidade na dignidade da pessoa humana, que exige que se inscreva no humano formas múltiplas do ser e a pluriversalidade no povo, que garante o reconhecimento do um no múltiplo. É preciso, então, trabalhar nos intervalos. No lugar de uma oposição universalidade/particularidade, penso se conseguiríamos trabalhar com pluriversalidades (MIGNOLO, 2000) e multiplicidades (CASTRO, 2015) como meio de fugirmos dessa oposição que, ao fim, nos coloca sempre entre a solução da abstração universal ou do particular concreto e fazem com que o múltiplo e o singular nunca se encontrem nem se aproximem. Talvez esses dois termos se refiram a ideias e autores que se afastem e se aproximem em medidas diferentes. Mas ambos servem a fazer do povo a performatividade que seja "povos" e fazer da "pessoa humana" a performatividade das múltiplas formas de "ser".

Isso significa tomar o terceiro espaço da enunciação entre o Eu e o $V_{o c} \hat{}^{16}$, agora como o povo que exerce o poder constituinte originário e a pessoa humana que será subjetivada nesse processo, e percebermos que há nesse intervalo zonas de coincidência e zonas de brutal afastamento entre esses sujeitos do performativo jurídico e, com isso, precisaremos usar ambos como estratégia política e jurídica. Primeiro para significar

16 Para Homi Bhabha, o Terceiro Espaço da enunciação - "que representa tanto as condições gerais da linguagem quanto a implicação específica do enunciado em uma estratégia performativa e institucional da qual ela não pode, em si, ter consciência" (BHABHA, 2013, p. 72). Usando outros conceitos, lembro que para Butler nem todo performativo alcança os efeitos que pretende ou, na linguaguem de Austin, nem todo performativo é felicitous, mas mesmo um ato que não produz os efeitos intencionados por quem o profere é um agir (Idem, p. 15-19). Ou seja, o ato pode caracterizar um agir quando sua força ilocucionária é produzida, ainda que dela não decorram os efeitos intencionados de sua dimensão perlocucionária. E é nesse intervalo entre agir e efeito, entre força ilocucionária e efeito perlocucionário, entre o momento do proferimento e os efeitos por ele produzidos ou não que é possível ressignificá-lo. A possibilidade de ressignificação depende, então, do tempo diferido, do espaço-tempo entre o momento da fala e os efeitos produzidos (Idem, p. 14). Esse espaço-tempo é o que Gould chama de illocutionary suspense ou perlocutionary delay (1995, p. 28) e que Homi Bhabha identifica como o Terceiro Espaço (da enunciação) (2013, p. 71-72), que nos mostra outra possibilidade que, no caso do Direito, pode trazer um potencial desejado a propostas expansivas da narrativa do humano no constitucionalismo democrático. 
que a coincidência como sujeito "da" e "na" lei é ao mesmo tempo violência e autonomia, já que essa "lei" aqui é o Direito, a Constituição e o constitucionalismo e isso irá significar que não se trata mais do sujeito autônomo centrado e voltado para si dos moldes kantianos, mas de uma ação em que o sujeito é produto e produtor e, assim, deixamos para trás no texto o sujeito prévio, o sujeito insular que sozinho constrói a si mesmo. Segundo para saber que os afastamentos não devem ser assimilados ou absorvidos, mas sempre tomados como o que se acrescenta de modo a desconfirmar a norma, ou seja: a multiplicidade das vivências e das corporalidades, a multiplicidade do ser pessoa daqueles que até então não foram feitos povo ou sujeito não devem ser "incluídas" na matriz, mas tomadas de modo que sejam acrescentadas nessas categorias de maneira que desconfirmem continuamente a matriz.

É essa articulação pluriversalidade-multiplicidade que quero chamar de "expansividade", na linha do que Homi Bhabha (2013) expressa ao falar sobre "acrescentar sem somar". Essa articulação, contudo, feita em uma leitura performativa-decolonial, não é uma de "tolerância", "multiculturalismo" ou "pluralismo liberal", uma vez que tais teorias, leituras ou epistemologias não parecem romper com a colonialidade e com o ideal branco cissexual e masculino da matriz colonial tomado como universal e neutro ${ }^{17}$. Discutindo o povo como performativo, a partir de uma visão decolonial, o que se percebe é que na homogeneização de particularidades informadas por um "ideal", as corporeidades são recusadas em nome de um "neutro" e "universal". Mas essa operação não acontece - e nem é possível - e o que realmente aparece é que esse ideal é um ideal masculino, europeu, branco, cissexual. Quando tomamos o corpo como fonte de conhecimento, percebemos que sexo, gênero e raça funcionam como linguagens de compreensão dos corpos e que tal linguagem, em

\footnotetext{
17 Para críticas ao multiculturalismo Paul Gilroy (2002, p. 37), Elisa Larkin do Nascimento (2003, p. 92-93) e Eduardo Viveiros de Castro (2015, p. 65). Sobre o multiculturalismo como multiracismo, Cf. Nelson Maldonado-Torres (2008, p. 105). Criticando o pluralismo liberal Mcclintock (2010, p. 27). Criticando a ideia de tolerância como racismo e assimilação Nascimento (2016, p. 111).
} 
uma matriz cis-hetero-colonial de organização de saber e poder cria uma normatização desses corpos e, com isso, a ideia de um "povo" como constatação contribui para esse processo. Quando, do contrário, tomamos povo como criação, essa abertura nos permite acrescentar essas corporeidades sem somar: usar a différance, como adiamento de um sentido pronto, no lugar da diferença, perceber que é preciso usar o excesso $d(n)$ a linguagem dos corpos falantes para permitir a esse povo sempre mais, para caber nessa universalidade uma expansividade. Acrescentar sem somar, ou pensar com pluriversalidades é entender que conceitos como esse precisam ser submetidos a narrativas que promovam uma abertura hermenêutica; não para "incluir o diferente", em um procedimento que acaba por reduzir o diferente no formato liberal, mas para perceber que "só há diferentes". No lugar de um que engloba todos - mas que na verdade silencia esse "todos" - o múltiplo que não se reduz.

Há uma perda - que não lamento - ao abandonar o constatativo: ao invés da autoridade persuasiva do povo soberano pré-existente e evidente que se reconhece no documento constitucional, a noção do povo performativo exige um "fazer o povo", repetidamente e sempre. Esse fazer trabalha nos intervalos: tanto naquele entre declarar e produzir o efeito de um "povo" - efeito sempre adiado, como différance -, quanto no intervalo entre subjetividades e universalidade: cada nova subjetividade vivida, narrada, transformada em identidade, reconhecida, adia mais um pouco o chegar da universalidade, "introduz a temporalidade do entre-lugar" (BHABHA, 2013, p. 240). Essa perda, então, é inevitável. Ela é provocada repetidamente pela própria referência a "povo" - reconheça-se ou não seu caráter performativo. Isso porque, por sua carga de "complexa estratégia retórica de referência social", o seu uso como "alegação de ser representativo provoca uma crise dentro do processo de significação e interpelação discursiva" (BHABHA, 2013, p. 237): cada vez que usado como entidade representativa é provocada a sua própria ruptura pela alegação dos que "não estão". A diferença, no entanto, é que abandonado o caráter autoevidente dessa categoria, poderá haver algum 
espaço para que este que nela não está seja não incluído em uma matriz normativa já dada, mas, mais do que isso, possa deslocar e adiar de novo e sempre a força representativa desse povo, sem abandonar seu uso ${ }^{18}$.

Usar essa leitura performativo-decolonial permite, portanto, que contranarrativas sobre quem é o povo possam ser utilizadas e desloquem o sentido teórico desse povo, além de não só provocar inclusão, mas também mudando o sentido do povo que se multiplica. Isso não significa abandonar o uso "pedagógico" (BHABHA, 2013, p. 237) de um conceito como esse, mas pensar que a cada vez que ele é usado, e a cada vez que ele é usado por aqueles recusados, inscreve-se novamente o povo. Talvez, assim, ele possa ser a própria fronteira entre uma narrativa universal de nação e as individualidades de corpos múltiplos e únicos. Se nem tanto tem essa força, certamente ele "representa o tênue limite entre os poderes totalizadores do social como comunidade homogênea, consensual e suas forças que significam a interpelação mais específica a interesses e identidades contenciosos" mas não é "nem o princípio nem o fim da narrativa nacional" (BHABHA, 2013, p. 238), para fazer possível a narrativa expansiva que proponho.

A operação é a de acrescentar sem somar: as diferentes corporalidades, em seu excesso, em seu escândalo, não comportam soma, em que individualidades desaparecem ou se homogeneízam ao serem incorporadas no universal. Ou ainda, a soma pressupõe um reduzir a igual categoria para que se realize o cálculo e se apresente "um" número, reduzindo o múltiplo ao um, ao universal. Além disso, essa leitura como pluriversalidade faz desse povo "povos" contra as narrativas racistas e sexistas de nação baseadas

\footnotetext{
18 Assim, como sustenta Bhabha: "Temos então um território conceitual disputado, onde o povo tem de ser pensado num tempo-duplo; o povo consiste em "objetos" históricos de uma pedagogia nacionalista, que atribui ao discurso uma autoridade que se baseia no pré-estabelecido ou na origem histórica constituída no passado; o povo consiste também em "sujeitos" de um processo de significação que deve obliterar qualquer presença anterior ou originária do povo-nação para demonstrar os princípios prodigiosos, vivos, do povo como contemporaneidade, como aquele signo do presente através do qual a vida nacional é redimida e reiterada como um processo reprodutivo (BHABHA, 2013, p. 237).
} 
no ideal da colonialidade, contra a oposição de um "povo" como discurso nacional homogeneizante e universal e detentor da história contra "povos" como parte de culturas localizadas a serem incorporadas a essa massa que esmaga o múltiplo. Se relermos, por exemplo, a história brasileira como história excludente de povos e de sujeitos em nome de um "povo brasileiro como democracia racial" e percebemos que essa narrativa é a da criação do indesejado nos corpos de homens e mulheres "desviantes" do gênero e da raça, desviantes do ideal colonial (MAGALHÃES GOMES, 2018), percebemos que etnocêntricos somos nós e junto com falar da colonialidade de teorias e práticas europeias temos que enxergá-la em nós mesmos para sermos capazes de permitir esse "povo" como pluriversalidades. Quando faço essa leitura e trago para o centro dela o "corpo", quero que as corporalidades antes produzidas como abjetas agora sejam nossa forma de reinscrever o discurso do humano no Direito.

Fazer essa leitura também significa buscar diminuir a lacuna entre "nós, o povo, criamos a norma X" e o da sua forma passiva "nós, o povo, devemos obedecer a x" (DOUZINAS, 2009, p. 42), sendo esse último povo e sujeitos ao mesmo tempo. Assim, fazer o povo se expandir vai ter por consequência permitir a expansão de "pessoa humana" e nisso acredito porque, sendo a subjetivação sujeição e subjetivação, como sujeito da e na lei, a pluriversalidade permite pensar outras formas de "ser". Movimentos expansivos, então, também me parecem acontecer quando submeto a dignidade da pessoa humana a uma leitura performativo-decolonial. O que sustento, primeiro, é: ao afirmar a dignidade da pessoa humana como fundamento do Estado Democrático de Direito, a Constituição faz uma declaração com força de compromisso, de que o Estado sempre se fundará nessa dignidade. A estrutura temporal e verbal aqui não é de constatação. Essa declaração é um performativo. Isso significa que a sua força (ilocucionária) é a de um compromisso e que ela pode ou não produzir os seus efeitos (perlocucionários) de, efetivamente, reconhecer (ou conceder) humanidade e construir dignidades. Essa produção de efeitos, contudo, pode ser uma produção que mantém ou que subverte 
sentidos de humanidade e dignidade. No primeiro sentido, quero dizer que os efeitos podem ser produzidos mantendo a cadeia histórica de significados sobre o humano que, aqui, identifico na "colonialidade do ser" como a colonialidade dos corpos por uma linguagem articulada de sexo, gênero e raça. Isso significaria que a "concessão" de humanidades se produziria como o que chamo de distribuição diferencial de humanidade. Esse efeito, contudo, pode se constituir como uma expansão do humano quando ele se fizer por uma iterabilidade subversiva: repetir o performativo nas margens ou intervalos da colonialidade.

Essa dignidade declarada não é real. Precisa ser, uma vez assumida como compromisso, performada como ação. Ocorre, contudo, que não só a realidade da atuação, da vivência, das relações do Estado com os sujeitos e desses entre si produz indignidades que podem ser contestadas diante da interpretação dominante assumida por doutrina e jurisprudência, mas os próprios termos postos pela concepção dominante de leitura da dignidade da pessoa humana produz indignidades. No lugar de pensar na dignidade do sentido kantiano - "homens não tem preço, não podem ser instrumentalizados porque são em si dignos" -, as ideias de relacionalidade, dependência, solidariedade, de relação com o outro e de correspondência solidária do ser-em-comum podem nos levar a um outro caminho. Isso significa que não uso o outro não apenas porque ele é digno em si como essência, mas porque: (i) não o usar é ao mesmo tempo causa e efeito dessa dignidade e a relação é, portanto, circular; (ii) não o usar, porque funcionamos na relacionalidade e precisamos e dependemos uns dos outros, em nossos processos de subjetivação que não são "o dar a lei a si"; e (iii) não o usar, porque vivemos em uma relação com o outro de correspondência solidária e essa deverá ser sempre inscrita para que possamos nos dizer "dignos".

E aqui volto a colocar uma pergunta: o que fazer com esse "humano" se ele não é um sujeito digno em si mesmo e nem aquele que dá a si mesmo a lei universalizável? O que fazer diante de um sujeito que é em "processo" tanto como subjetivação constante e iterável quanto como processo de sujeição e subjetivação? Se o sujeito não existe antes do ato de dar-se a 
lei e nem é apenas resultado dessa lei, como o pensamos agora? A teoria dominante da dignidade da pessoa humana e dos "direitos fundamentais" é aquela mesma liberal e moderna que orientou os direitos humanos, ou seja: colonial, eurocêntrica, universalizante e abstrata. Isso significa que são formados tanto a partir de uma noção de propriedade, mas também pressupõem uma ideia de liberdade e de dignidade marcadas pelo liberalismo. Essas ideias têm (ou produzem) ao fundo uma forma de compreender o "humano" ou, melhor dizendo, um entendimento a respeito de uma certa "natureza" ou "essência" humana e como tal, portanto, supostamente presentes e identificáveis em todo e qualquer "humano" ou em toda ou qualquer forma de conceber "humanidade". Essa ideia foi

[...] imprescindível para a elaboração do direito moderno. No processo da configuração liberal de direitos surge uma proposta de universalização formulada legalmente a partir da unicidade da natureza humana. [...]. É essa essência do verdadeiro humano que vai alicerçar a ideia de direitos universais (HOLANDA, 2008, p. 14).

Nesse entender, o mesmo processo que, de forma geral, se observa na racionalidade moderna que opõe e hierarquiza sujeito/objeto, racional/ mítico, tradição/modernidade, barbárie/civilização (QUIJANO, 1991, p. 45), se observa na construção da racionalidade dos direitos humanos que, seja dando ao processo o nome de gerações ou dimensões de direitos humanos, acaba por guardar a mesma noção: a de um processo "evolutivo" de assimilação de valores eurocêntricos (CASTILHO, 2013, p. 38) encapados como se universais fossem, como se naturais fossem.

Além de me juntar a uma crítica já bastante difundida sobre como a racionalidade europeia de direitos humanos é criada a partir da propriedade como forma de organização social e forma de produção de valor (CASTILHO, 2013, p. 23) - incluindo, então, produção de valor sobre o humano -, entendo que é preciso sempre ter em conta que ela também se baseia em uma concepção específica de sujeito e de liberdade. Assim, 
não apenas uma política de direitos fundamentais fundada na propriedade é danosa, mas ao mesmo tempo a sua fundação em uma noção abstrata de liberdade - e, portanto, de dignidade - igualmente o é. Partindo disso, no lugar de definir a "pessoa humana" ou a "dignidade da pessoa humana", entendo necessário realizarmos um descentramento conceitual para pensar o "fazer" dessa dignidade e por isso falei aqui em "dignidades" e em outra oportunidade falei em dignidade atribuível (MAGALHÃES GOMES, 2019). Assumo, então, que o humano está no intervalo (TIMM, 2008, p. 125), que é humano em processo de: não há um definitivo do humano e o tomo apenas em seu caráter de processo e fronteira como incompletude e precariedade, não há sujeito completo, pronto, não há um processo de subjetivação finalizado, não há uma autonomia autofundada e centrada. Há um contínuo de performatividade, há uma iterabilidade de reinscrição e/ou ruptura da norma, um viver na violência. Do mesmo modo, não há nem um voluntarismo - como uma escolha - nem um determinismo das normas que o formam. Quando juntamos isso ao fato de que essa violência é violência no corpo e violência na linguagem, de raça e de gênero, esse humano "em processo" exige uma dignidade atribuível que, também em processo, se comprometa com a diminuição das indignidades construídas pela distribuição diferencial de humanidade própria da colonialidade. Exige abandonar o sujeito moderno uma vez que, se esse sujeito pode controlar a natureza, ele pode controlar os que "são" natureza. Esse sujeito racional conquistador dominante se legitima como controlador dos que são corpo, se legitima como padrão para se encaixar os que são corpo e justificar decisões e atuações do direito: ignoro as dimensões da corporeidade - raça classe gênero sexo - para poder encaixar o sujeito.

Só conhecemos os corpos - e os sujeitos - como corpos generificados. Igualmente, na colonialidade, a raça se torna marca de identificação e conhecemos os corpos na linguagem da racialização. Quando os estudos de gênero e os estudos decoloniais nos mostram que a normatividade binária da modernidade guarda em si uma exclusão fundante (humanos e não humanos), percebemos que a concepção jurídica dominante da 
"pessoa humana" que, de modo geral corresponde a identificá-la com o "indivíduo" sujeito da modernidade, levamos a conclusão de que: (i) essa é apenas uma das muitas concepções de pessoa, (ii) essa concepção passou de modo inquestionado pelas questões de constituição racial e generificada dos sujeitos e corpos, como recusa do corpo como categoria filosófica, jurídica e política, recusa que permite o controle dos corpos fora da norma para manter os processos de desumanização da colonialidade.

Quando a teoria da performatividade nos mostra que o sujeito/ identidade/gênero é instável e quando a teoria decolonial nos apresenta sujeitos múltiplos, uma nova noção de pessoa humana precisa ter lugar no Direito, rompendo com a modernidade e seus paradigmas para fazer caber a realidade múltipla do humano. Se só nos conhecemos por meio da linguagem, se nos constituímos na e pela linguagem, a linguagem jurídica ganha ainda mais poder. Nessa linguagem, o sujeito de direitos é a entrada da pessoa humana. Ao questionarmos o "humano" sob as teorias da performatividade e da decolonialidade, percebemos que também "pessoa humana" é múltipla (SEGATO, 2005), instável (BUTLER, 2015) e divisível (STRATHERN, 2006) e que é formada na relacionalidade e a linguagem/ imagem/identidade que cria sobre si é estratégia de sobrevivência.

Quando as teorias performativas e decoloniais nos permitem desfazer a binariedade do gênero e a "verdade" da raça e mostrar que nele os sujeitos são instáveis, plurais, múltiplos, transitórios, podemos dizer que as "pessoas humanas" são instáveis, plurais, múltiplas, transitórias. Por isso, não se trata de usar a dignidade da pessoa humana como ferramenta de tolerância nem de inclusão, nem de igualdade nem de diferença, mas como ferramenta de performar as possibilidades expansivas, uma ferramenta de denúncia das linguagens restritivas que serve não a instaurar o humano como conceito, mas a desconfirmar continuamente esse humano. Por isso, introduzir o "corpo" como fonte de conhecimento no Direito significa desconfirmar o "eu" intérprete. Passa por exigir repensar as linguagens sobre pessoa humana para, reconhecendo a multiplicidade dos corpos, reconhecer a radical singularidade e, reduzindo as condições 
de precariedade a que diferentes corpos estão sujeitos, permitir mais, permitir que a formação da subjetividade no/pelo Direito seja um pouco menos violenta.

Minha proposta é a proposta de uma teoria do humano no jurídico que seja relacional, "em processo", incompleta, aberta ao outro. Uma alteridade radical (SEGATO, 2006), pluriversal e multíplice, aberta ao desfazimento mútuo porque reconhecedora de que somos, ao fim, sempre incrível e inegavelmente precários. Mais do que, contudo, abertura ao outro, "abertura ao múltiplo". Não há um outro. Há múltiplos. Há a necessidade de uma alteridade aberta e expansiva que não só permita que eu veja esses outros, mas que antes disso permita que eles me vejam e me desfaçam e desconfirmem meu mundo, permitir que o outro me desfaça e me mostre em minha incompletude, que a relacionalidade seja o espaço em que o outro me faça estranho a mim mesma, que eu me desconheça e mais do que isso, que ela seja esse espaço em que o outro me mostre aquilo que em mim e em minhas resistências ideológicas contribuem - ou são mesmo um fato fundamental - para que a humanidade seja desigualmente atribuída. Estas noções implicam uma abertura, "uma exposição voluntária ao desafio e à perplexidade imposta a nossas certezas, pelo mundo dos outros", o limite é imposto pelos outros e completo pelas corporalidades outras, "pelo que é alheio a nossos valores e às categorias que organizam nossa realidade, causando-nos perplexidade e mostrando sua falibilidade, seu caráter contingente e, portanto, arbitrário". Essa abertura deve ser guiada pelo "papel da alteridade com sua resistência a confirmar nosso mundo, as bases de nossa comunidade moral" (SEGATO, 2006, p. 225). Para isso, preciso perceber que não sou completa. Que sou múltiplas.

\section{Considerações finais}

No começo do texto, parti da percepção do Direito como ato de fala e, assim sendo, constituindo em significativa extensão, um ato de fala performativo. Falar em performatividade nos leva à linguagem como força e 
efeito: a força ilocucionária do ato de fala, a produção perlocucionária de efeitos. A força de compromisso da Constituição e o efeito da produção de humanidade. Do mesmo modo, nos leva a identificar que a cadeia histórica de significados que faz um performativo, para os objetos deste trabalho, é a colonialidade que tem por dicotomia fundante a oposição entre humanos e não humanos. Com essas afirmações, podemos refletir sobre a relação das duas matrizes teóricas utilizadas para perceber que, quanto mais o Direito - como teoria, como texto, como narrativa, como ato de fala, como Constituição - reproduza os sentidos da colonialidade, mais o efeito será o de produzir "desumanidades".

Defendo, então, trabalhar no intervalo entre força e efeito para que o efeito seja expansivo. Fiz esses movimentos na busca de construir a seguinte ideia: podemos entender que performativos "funcionam" e produzem efeitos mesmo quando não atingem a intenção do falante "original" e mesmo sem - ou distante no espaço e no tempo - a presença desse falante. A intenção não governa o ato performativo e sua produção de efeitos. É sua produção dentro (como manutenção e ou repetição) ou contra (como subversão ou reinscrição de sentidos) uma matriz ou cadeia histórica de significados que o faz funcionar. Funcionar, assim, significará iterabilidade, a capacidade de reprodução que faz com que um ato de fala, sem um referente externo que serviria a descrever, continue a fazer ou produzir sentido. Longe da presença, trabalhemos com narrativas outras, com teorias outras, com a utilização dos termos e institutos jurídico-constitucionais por aquelas que vivem a norma, que vivem contra a norma para se constituírem dignas. Longe da presença, trabalhemos nesses intervalos, nesse espaço-tempo em que outras histórias sobre o que seja "ser um povo" ou ser um "sujeito digno" possam desrecalcar narrativas hegemônicas sobre a Constituição. Longe da presença, trabalhemos nos intervalos entre ser povo e ser pessoa digna, realizando, na tensão do constitucionalismo democrático já descrita, aproximações e confusões entre essas duas posições de sujeito, entre quem fala e para quem se fala, performando uma outra narrativa constitucional. 
Para tentar inscrever outro sentido no "humano" para o Direito que não os dados pela colonialidade de raça e de gênero, recorri a uma articulação entre performatividade e decolonialidade. Com isso, cheguei à compreensão de que entre a declaração e a realidade, entre a força e a produção de efeitos reside o lugar de fazer diferente. Ficar, então, entre povo e pessoa humana foi a minha resposta para uma expansividade: ficar entre "povos" como pluriversalidades e "pessoas" como multiplicidades, em uma tensão ou conflito que não precisa nem deve se resolver, um conflito que, se corporificado, não tem como se resolver. Ler a Constituição como performatividade, no entanto, pode significar o risco de uma abertura sem fim ou limites. O limite, no entanto, está justamente no "corpo". O limite na interpretação do humano está na responsabilidade de diminuir as condições de distribuição diversas de precariedade que impõem aos condenados da raça e do gênero na matriz branca e cis-heterconforme uma distribuição diferencial de humanidade. A Constituição cria e possibilita sujeitos, como violência material. Assim, se a vida do constitucionalismo é o embate entre democracia e direitos fundamentais, com o exercício do dissenso por um constitucionalismo radical, a vida do humano no direito para o constitucionalismo radicalmente comprometido é uma tensão entre "povo" e "pessoa humana" sob os limites que os corpos impõem repetidamente.

Defendo que o humano no Direito precisa ser performado. Ele nunca chega, ele está na fronteira, ele é a fronteira e deveríamos celebrar isso. As humanidades devem ser reinscritas continuamente, citadas e, nos marcos das corporalidade de sexo, de gênero e raça, citadas de modo subversivo e expansivo. O humano exige, portanto, uma teoria que tenha em mente que a subjetivação é um processo relacional, que o corpo é maleável como linguagem e na linguagem, que a autonomia se constrói na relacionalidade, e que o sujeito que dá a si mesmo uma lei é ao mesmo tempo "povo" e "pessoa humana". Para isso, deve levar em conta: a) um critério hermenêutico do constitucionalismo radicalmente comprometido com a produção de sujeitos dignos na performatividade que expande quem são os sujeitos possíveis do humano; b) um critério ético da humanidade como precarie- 
dade, incompletude, "em processo de" e que reconhece a si e aos múltiplos em sua relacionalidade, incompletude e multiplicidades; c) um critério simultaneamente político e jurídico da autodeterminação e autodeclaração como parte da articulação entre povo e pessoa humana para podermos falar com um pouco mais de aproximação de um sujeito autônomo; d) um critério filosófico da différance como inscrição e adiamento de sentido, a exigência do pensar que se sabe sempre temporário; e e) um critério crítico do pensar com a decolonialidade, afastando binariedades hierarquizantes e evitando o impulso classificatório e definidor de humanidade.

Esse uso de critérios deve partir da recusa de universalismos, do sujeito centrado em si; do sujeito autônomo e soberano; para que o outro não seja reduzido ao eu. É preciso ver o múltiplo no outro, saber que ele é muitos. Para isso ser possível, é preciso saber que o "eu" são muitos. Por isso partir de uma teoria de gênero performativa e de uma teoria decolonial para compreender as multiplicidades, essa (re)inscrição performativa que é a experiência do eu e para perceber que a relação eu/outro não pode ser esse olhar de fora que categoriza. Não há "um outro" por quem me responsabilizo. Há múltiplos, há pluriversos. Há a necessidade de uma alteridade mais radical. Aberta e expansiva que não só permita que eu veja esses outros, mas que, antes disso, permita, que ele me veja e me desfaça e desconfirme meu mundo. E isso só é possível quando e se reconheço que não sou completa. Que sou precária. Que sou múltiplas. Para a justiça como alteridade, a ética da precariedade e uma hermenêutica comprometida: não, não somos dignos. Nos fazemos dignos. Permitimos e produzimos condições para que os outros assim se façam e nos responsabilizamos por esse fazer, de modo recíproco. Não somos ainda humanos. E ainda um dia o seremos?

\section{Referências}

ANDRADE, Luma Nogueira de. Travestis na escola: assujeitamento e resistência à ordem normativa. Luma Nogueira de Andrade. Rio de Janeiro: Metanoia, 2015. 
AUSTIN, John L. How to do things with words. 2. ed. Harvard: Harvard University Press, 1975. https://doi.org/10.1093/acprof:0so/9780198245537.001.0001

BHABHA, Homi. O local da cultura. Trad. Myriam Ávila, Eliana Lourenço de Lima Reis, Gláucia Renata Gonçalves. 2. ed. Belo Horizonte: UFMG, 2013.

BRASIL, Supremo Tribunal Federal. Ação Direta de Inconstitucionalidade. ADI 4275. Tribunal Pleno. Rel. Min. Marco Aurélio. 2018b. Disponível em: http:// www.stf.jus.br/portal/geral/verPdfPaginado.asp?id=400211\&tipo=TP\&descricao $=$ ADI\%2F4275. Acesso em: 10 de out. 2018.

BUTLER, Judith. Bodies That Matter: On the Discursive Limits of "Sex". New York: Routledge, 1993.

BUTLER, Judith. Excitable Speech: a politics of the performative. New York: Routledge, 1997a.

BUTLER, Judith. Relatar a si mesmo: crítica da violência ética. Trad. Rogerio Bettoni. 1 ed. Belo Horizonte: Autentica, 2015b.

BUTLER, Judith. The Psychic Life of Power: Theories in Subjection. Stanford: Stanford University Press, 1997b.

CASTILHO, Natalia Martinuzzi. Pensamento descolonial e teoria crítica dos direitos humanos na América Latina: um diálogo a partir da obra de Joaquín Herrera Flores. 2013. 197 f. Dissertação (Mestrado em Direito). Programa de Pós-Graduação em Direito, Universidade do Vale do Rio dos Sinos, São Leopoldo, 2013.

CASTRO, Eduardo Viveiros de. Metafísicas canibais: elementos para uma antropologia pós-estrutural. São Paulo: Cosac Naify, 2015.

CHUEIRI, Vera Karam de. Constituição radical: uma ideia e uma prática. Revista da Faculdade de Direito UFPR, Curitiba, n. 58, p. 25-36, 2013. https:// doi.org/10.5380/rfdufpr.v58io.34863

COACCI, T. "Eu tenho um amo implacável: a natureza das coisas": discursos jurídicos acerca das transexualidades no Tribunal de Justiça de Minas Gerais (1989-2010). Revista Diálogo, Canoas, n. 24, p. 45-62, dez. 2013. Disponível em: http://www.revistas.unilasalle.edu.br/ index.php/Dialogo/article/ view/1304/993. Acesso em: 30 mar. 2017.

DERRIDA, Jacques. Assinatura Acontecimento Contexto. In: Margens da Filosofia. Trad. Joaquim Torres Costa e António M. Magalhães. Campinas: Papirus, 1991. p. 349-373. Comunicação original no Colóquio "A Comunicação" 
no "Congrès International des Societés de Philosophie de Langue Française", Montreal, agosto, 1971.

DERRIDA, Jacques. Declarations of Independence. In: DERRIDA, Jacques. Negotiations. Trad. Elizabeth G. Rottenberg. Stanford: Stanford University Press, 2002, p. 46-54.

DOUZINAS, Costas. O fim dos direitos humanos. São Leopoldo: Unisinos, 2009.

FELMAN, Shoshana. The scandal of the speaking body: Don Juan with J. L. Austin, or seduction in two Languages. Translated by Catherine Porter. Stanford: Stanford University Press, 2003.

FONSECA, Livia Gimenes Dias da. Despatriarcalizar e decolonizar o estado brasileiro: um olhar pelas políticas públicas para mulheres indígenas. 2016. 206 f. Tese (Doutorado em Direito). Programa de Pós-Graduação em Direito, Universidade de Brasília, Brasília, DF, 2016.

GILROY, Paul. O Atlantico Negro. Trad. Cid Knipel Moreira. São Paulo: Editora $34,2002$.

MAGALHÃES GOMES, Camilla de. Corpos falantes: a teoria do gênero como performatividade na perspectiva decolonial. In: SEMINÁRIO INTERNACIONAL FAZENDO GÊNERO, 11; WOMEN'S WORLDS CONGRESS, 13., Florianópolis. Anais eletrônicos [...]. [S. l: s. n.], 2017a. p. 1-13. Disponível em: http://www. en.wwc2017.eventos.dype.com.br/resources/anais/1518796654_ARQUIVO_ SToog-CorposFalantes-CamillaMagalhaesGomes.pdf. Acesso em: 28 ago. 2019. MAGALHÃES GOMES, Camilla de. "O juiz diante da desconstrução”. Revista de Estudos Constitucionais, Hermenêutica e Teoria do Direito, (RECHTD), São Leopoldo, v. 9, n. 2, p. 125-135, maio/ago. 2017b. https://doi.org/10.4013/ rechtd.2017.92.04

MAGALHÃES GOMES, Camilla de. "Os sujeitos do performativo jurídico: relendo a dignidade da pessoa humana nos marcos de gênero e raça". Revista Direito e Práxis, Rio de Janeiro, v. 10, n 2, p. 871-905, 2019. Disponível em: https://www.e-publicacoes.uerj.br/index.php/ revistaceaju/article/view/30194. Acesso em: 28 ago. 2019. https://doi.org/10.1590/2179-8966/2018/30194

MAGALHÃES GOMES, Camilla de. Sujeitos do performativo jurídico II: uma releitura do "povo" nos marcos de gênero e raça. Teoria Jurídica Contemporânea, Rio de Janeiro, v. 3, p. 64-97, 2018. Disponível em: https://revistas.ufrj.br/ index.php/rjur/article/view/16534/12539. Acesso em: 28 ago. 2019. https:// doi.org/10.21875/tjc.v3i1.16534 
MAGALHÃES GOMES, Camilla de. Têmis Travesti: as relações entre gênero, raça e direito na busca de uma hermenêutica expansiva do "humano" no Direito. 2017. 234 f. Tese de doutorado, Programa de Pós-graduação em Direito, Estado e Constituição, Universidade de Brasília, 2017c. Disponível em: http://repositorio. unb.br/bitstream/10482/23975/1/2017_CamilladeMagalh\%C3\%A3esGomes. pdf. Acesso em: 28 ago. 2019.

GOULD, Timothy. The Unhappy Performative. In: PARKER, Andrew; SEDGWICK, Eve Kosovsky. (ed.). Performativity and Performance. New York: Routledge, 1995. p. 19-44. https://doi.org/10.4324/9780203699928-1

GRUPO TRANSCRITAS COLETIVAS. Nós, Trans: Escrevivências de Resistência. [S. l.]: Editora LiteraTRANS, 2017.

HOLANDA, Marianna. Por uma ética da (In)Dignação: repensando o Humano, a Dignidade e o pluralismo nos movimentos de lutas por direitos. 2015. 205. f. Tese (Doutorado) - Programa de Pós-Graduação em Bioética, Universidade de Brasília, Brasília, DF, 2015.

KOZICKI, Katya. O problema da interpretação do direito e a justiça na perspectiva da desconstrução, O que nos faz pensar, Rio de Janeiro, n. 18, p. 145-164, set. 2004. Disponível em: http://oquenosfazpensar.fil.puc-rio.br/import/ pdf_articles/OQNFP_18_08_katya_kozicki.pdf. Acesso em: 20 jul 2015.

LARKIN, Elisa do Nascimento. $O$ sortilégio da cor: identidade, raça e gênero no Brasil. São Paulo: Selo Negro, 2003.

LUGONES. Maria. Rumo a um feminismo decolonial. Estudos Feministas, Coimbra,v. 22, n. 3, p. 935-952, set./dez. 2014. https://doi.org/10.1590/ S0104-026X2014000300013

MACIEL, Anna Maria Becker. Para o reconhecimento da especificidade do termo jurídico. 2001. 258 f. Tese (Doutorado). Programa de Pós-Graduação em Letras, Universidade Federal do Rio Grande do Sul, Porto Alegre, 2001.

MALDONADO-TORRES, Nelson. A topologia do Ser e a geopolítica do conhecimento. Modernidade, império e colonialidade. Trad. Inês Martins Ferreira. Revista Crítica de Ciências Sociais, Coimbra, v. 80, mar. 2008. pp. 71-114. https://doi.org/10.4000/rccs.695

MALDONADO-TORRES, Nelson. Sobre la colonialidad del ser: contribuciones al desarrollo de un concepto". In: CASTRO-GOMEZ, Santiago. GROSFOGUEL, Ramón (eds.). El giro decolonial: Reflexiones para una diversidad epistémica más allá del capitalismo global. Bogotá: lesco-Pensar-Siglo del Hombre Editores, 2007. p.127-167. 
MCCLINTOCK, Anne. Couro imperial: raça, gênero e sexualidade no embate colonial. Trad. Plinio Dentzien. Campinas: Unicamp, 2010.

MIGNOLO, W. Local Histories/Global Designs: Coloniality, Subaltern Knowledges, and Border Thinking. Princeton, NJ: Princeton University Press, 2000.

PELÚCIO. Larissa. "Toda Quebrada na Plástica”: Corporalidade e construção de gênero entre travestis paulistas. 2005. https://doi.org/10.5380/cam.v6io.4509 PELÚCIO. Larissa. Abjeção e desejo: uma etnografia travesti sobre o modelo preventivo de aids. São Paulo: Annablume; Fapesp, 2009.

QUIJANO, A. La modernidad, el capital y América Latina nacen el mismo día, entrevista dada a Nora Velarde. ILLA - Revista del Centro de Educación y Cultura, [S. l.], n. 10, pp. 42- 57, enero. 1991.

RESADORI, Alice Hertzog. Antidiscriminação e travestilidade no Brasil: critérios proibidos de discriminação e autodeclaração. 2016. 158 f. Dissertação (mestrado) - Centro Universitário Ritter dos Reis, Faculdade de Direito, Porto Alegre, 2016.

SEGATO, Rita Laura. Antropologia e direitos humanos: alteridade e ética no movimento de expansão dos direitos universais. Mana [online], [S. l.], v.12, n.1, p. 207-236, 2006. https://doi.org/10.1590/S0104-93132006000100008

SEGATO, Rita Laura. Gênero e colonialidade: em busca de chaves de leitura e de um vocabulário estratégico descolonial. E-cadernos CES (Online), [S. l.], v. 18, p. 1-5, 2012. https://doi.org/10.4000/eces.1533

SEGATO, Rita Laura. Santos e Daimones: O Politeísmo Afro-Brasileiro e a Tradição Arquetipal. 2. ed. Brasília, DF: EDUnB, 2005.

STRATHERN, Marilyn. O gênero da dádiva: problemas com as mulheres e problemas com a sociedade na Melanésia. Trad. André Villalobos. Campinas: Unicamp, 2006.

SOUZA, Ricardo Timm de. A dignidade humana desde uma antropologia dos intervalos: uma síntese. Veritas, Porto Alegre, v. 53 n. 2 abr./jun. 2008. pp. 120-149. https://doi.org/10.15448/1984-6746.2008.2.4464

VERGUEIRO, Viviane. Por inflexões decoloniais de corpos e identidades de gênero inconformes: uma análise autoetnográfica da cisgeneridade como normatividade. 2015. 244 f. Dissertação (Mestrado). Programa Multidisciplinar de Pós-Graduação em Cultura e Sociedade, Universidade Federal da Bahia, Salvador, 2016. Disponível em: https://www.academia.edu/25145724/ Por_inflex\%C3\%B5es_decoloniais_de_corpos_e_identidades_de_g\%C3\%A- 
Anero_inconformes_uma_an\%C3\%A1lise_autoetnogr\%C3\%A1fica_da_cisgeneridade_como_normatividade. Acesso em: 14 out 2015.

\section{Endereço Postal}

Centro Universitário de Brasília. Campus Universitário - SEPN 707/907 Asa Norte, Brasília - DF, CEP:70790-075 